\title{
ASSESSMENT OF DNA STRAND BREAKS AND TOTAL ANTIOXIDANT STATUS IN PATIENTS WITH TYPE 2 DIABETES WITH AND WITHOUT COMPLICATIONS: A CASE-CONTROL STUDY
}

\author{
NITHYA $\mathrm{K}^{1}$, ISABEL $\mathbf{W}^{1}$, ANGELINE $\mathbf{T}^{2}$, PRISCILLA AS ${ }^{1}$, ASIRVATHAM AJ ${ }^{3}$ \\ ${ }^{1}$ PG \& Research Department of Zoology \& Biotechnology, Lady Doak College, Madurai - 625 002, Tamil Nadu, India. ${ }^{2}$ Department \\ of Zoology, The American College, Madurai - 652 002, Tamil Nadu, India. ${ }^{3}$ Department of Diabetology, Arthur Asirvatham Hospital, \\ Madurai - 625 020, Tamil Nadu, India. Email: nithyadeiva@gmail.com
}

Received: 10 January 2017, Revised and Accepted: 27 January 2017

ABSTRACT

Objective: To evaluate the total antioxidant status (TAS) and the extent of DNA strand breaks (damage) as a measure of oxidative stress biomarkers in patients with Type 2 diabetes (with and without complications) and controls.

Methods: Blood samples were collected from 200 patients with Type 2 diabetes mellitus ( $\mathrm{n}=100$, with complications and $\mathrm{n}=100$, without complications) and 100 healthy individuals. Oxidative DNA damage was evaluated using alkaline single cell gel electrophoresis (comet assay). TAS was assessed by ferric reducing ability of plasma assay.

Results: TAS was found to be significantly lower in patients with Type 2 diabetes (with and without complications) compared to controls (p<0.001). Similarly, patients with complications of Type 2 diabetes mellitus had significantly lower TAS when compared to patients with diabetes (p=0.007). DNA damage analysis showed that the extent of damage was high in patients with diabetes mellitus (with and without complications) compared to controls $(\mathrm{p}<0.001)$. Fasting glucose and glycosylated hemoglobin level $\left(\mathrm{HbA}_{1 \mathrm{C}}\right)$ were found to be significantly higher in patients with diabetes than controls $(\mathrm{p}<0.05)$. Correlation analysis showed that there is no association between age, duration, sugar level, HbA ${ }_{1,}$ TAS, and DNA damage in patients with Type 2 diabetes mellitus.

Conclusion: Alterations in TAS and the extent of DNA damage were observed in patients with complications of diabetes mellitus indicate that oxidative stress is more in patients with complications when compared to patients without complications and healthy individuals. Therefore, further DNA damage and onset of complications in Type 2 diabetes mellitus could be prevented by counteracting the oxidative stress by therapeutic interventions using appropriate antioxidants.

Keywords: Hyperglycemia, Oxidative stress, DNA damage, Total antioxidant status, Type 2 diabetes mellitus, Vascular complication.

(C) 2017 The Authors. Published by Innovare Academic Sciences Pvt Ltd. This is an open access article under the CC BY license (http://creativecommons. org/licenses/by/4. 0/) DOI: http://dx.doi.org/10.22159/ajpcr.2017.v10i4.17020

\section{INTRODUCTION}

Diabetes is a group of metabolic diseases characterized by high levels of blood sugar (hyperglycemia) which results from defects in insulin production and/or insulin action, and impaired function in the metabolism of carbohydrates, lipids, and proteins which lead to long-term health complications [1]. The vascular complications are the major causes of morbidity and mortality in patients with diabetes mellitus [2]. Several mechanisms are involved in the pathogenesis of diabetic complications such as increased production of advanced glycation end products, enhanced polyol pathway, activation of protein kinase C isoforms, and enhanced oxidative stress [3-6]. Evidences suggest that enhanced oxidative stress plays an important role in the pathogenesis of diabetes and its complications [7-9]. Free radical and oxidative stress-induced complications from diabetes mellitus include coronary artery disease, neuropathy, nephropathy, retinopathy [10], stroke [11], and foot ulcer [12]. Oxidative stress in response to hyperglycemia in patients with diabetes induces peroxidation of cellular membrane lipids, increased oxidative modification of amino acids, and DNA [13]

Hyperglycemiainduces free radicals and impairs/diminishes antioxidant defense mechanism in patients with diabetes. Antioxidant defense mechanisms include both enzymatic and non-enzymatic pathways. Their functions are to counterbalance toxic reactive oxygen species in human system [14]. Antioxidants play a vital role as preventive factors in the pathogenesis of vascular complications in patients with diabetes. Therefore, the measurement of the antioxidant capacity in body fluids proved to be an important prognostic or diagnostic guide in patients with diabetes for implementation of antioxidant therapy $[15,16]$. It has been suggested that dietary intake of antioxidants reduces oxidative stress and also protective against DNA damage [17].

Several studies have shown that oxidative DNA damage in lymphocytes and plasma antioxidant potential are used as biomarkers to measure oxidative stress. The most widely used method for assessment of DNA damage is the alkaline comet assay that helps to measure the single/ double strand DNA breaks, alkali labile sites, DNA cross-links, and apoptotic nuclei in the cells [18].

Hence, the present study was focused to evaluate the total antioxidant status (TAS) and the extent of DNA damage as a measure of oxidative stress biomarkers in patients with Type 2 diabetes (with and without complications) and controls.

\section{METHODS}

\section{Study subjects}

South Indians, who were between the age group of 35 and 55 years, were included in the study. The study participants consisted of 100 patients with Type 2 diabetes with complications and 100 patients with Type 2 diabetes without complications and 100 healthy individuals as controls. Informed consent was obtained from the study participants. Ethical clearance was obtained from the Hospital Ethics Committee. The patients were characterized as diabetes mellitus based on the fasting blood glucose concentration $>7.0 \mathrm{mmol} / \mathrm{L}$. Individuals with normal 
blood glucose concentration $<7.0 \mathrm{mmol} / \mathrm{L}$ were considered as controls. A standard questionnaire was used to collect information about age, sex, fasting glucose, glycosylated hemoglobin $\left(\mathrm{HbA}_{1 \mathrm{c}}\right)$, duration of diabetes, family history, risk factors, and complications of diabetes.

\section{Plasma TAS}

TAS was measured spectrophotometrically by the ferric reducing ability of plasma (assay). At low pH, reduction of ferric tripyridyl triazine (Fe III) complex to ferrous form (which has an intense blue color) was monitored by measuring the change in absorption at $593 \mathrm{~nm}$. The change in absorbance was, therefore, directly related to the combined or "total" reducing power of the electron-donating antioxidants present in the reaction mixture [19].

\section{Single cell gel electrophoresis (comet assay)}

Single-cell alkaline gel electrophoresis was employed to assess the level of DNA damage in peripheral lymphocytes by two-layer method according to Tice et al., 2000 [20] with slight modifications according to Singh et al., 2000 [21]. All steps carried out for alkaline comet assay were done at low temperature and with dim light to minimize the possibility of DNA damage.

\section{Lymphocyte separation}

Peripheral blood lymphocytes were separated by centrifugation at 1600 rpm for 20 minutes in lymphocyte separation media (Hisep ${ }^{\mathrm{TM}} \mathrm{LSM}$ 1077, Mumbai). After centrifugation, the separated lymphocytes were washed and resuspended in phosphate-buffered saline. Then, the cell suspension was used for analysis.

\section{Preparation of cell microgels on slides}

The first gel layer was made by adding $100 \mu \mathrm{l}$ of normal melting agarose $(0.7 \%)$ onto a fully frosted microslide and was gently covered with a coverslip. The coverslip was removed after the agarose solidified at $4^{\circ} \mathrm{C}$. About $30 \mu \mathrm{l}$ of the cell suspension was mixed with $70 \mu \mathrm{l}$ of low melting agarose $(0.5 \%)$ at $37^{\circ} \mathrm{C}$, and the mixture was quickly layered to the first gel layer. The coverslip was placed over the gel layer and kept at $4^{\circ} \mathrm{C}$ for solidification.

\section{Cell lysis and DNA unwinding}

After solidification, the coverslips were removed from the cell microgels, and it was immersed in fresh ice-cold lysis buffer (pH 10) at $4^{\circ} \mathrm{C}$ for overnight. After draining, microgel slides were treated with DNA unwinding solution ( $\mathrm{pH} 13)$ for 30 minutes at $4^{\circ} \mathrm{C}$ for the disruption of double-stranded DNA to single-stranded DNA and to express alkali labile sites as single-strand breaks.

\section{Electrophoresis, neutralizing, and staining}

Electrophoresis was then conducted with an electric field of $1 \mathrm{~V} / \mathrm{cm}$ for 15 minutes. After electrophoresis, the microgels were placed in a neutralization buffer ( $\mathrm{pH}$ 7.5) for 10 minutes and stained with ethidium bromide $(10 \mu \mathrm{g} / \mathrm{ml})$. The slides were analyzed immediately after staining.

\section{Microscopic examination and comet scoring}

The slides were examined at $\times 20$ magnification using an inverted fluorescent microscope (Optika) equipped with appropriate filters attached to a video camera. At least, 5-10 images were captured per slide for 100 cells to evaluate the percent of DNA damage. The cells were scored visually on the basis of the comet appearance and categorized as undamaged (normal cells), mildly damaged cells, and highly damaged cells as comets. The extent of DNA liberated from the head was directly proportional to the DNA damage. While scoring, comets seen in edges, air bubbles, and overlaps were rejected.

\section{Statistical analysis}

Student's t-test and Mann-Whitney rank sum test were performed to compare the significance between two variables. Pearson's correlation coefficient was used to find a correlation between two variables. Statistical analysis was performed using SigmaStat 11.0 version software, and $p \leq 0.05$ was considered statistically significant.

\section{RESULTS}

The clinical characteristics of patients with Type 2 diabetes and the control groups are shown in Table 1 . The mean values of fasting glucose and $\mathrm{HbA}_{1 \mathrm{C}}$ were $12.7 \pm 3.9 \mathrm{mmol} / \mathrm{L}$ and $8.9 \pm 1.8 \%$, respectively, in patients with complications. Among the patients with Type 2 diabetes, $56 \%$ of them had neuropathy, $18 \%$ had heart disease, $16 \%$ had vascular disease, $6 \%$ had nephropathy, $2 \%$ had foot ulcer, $1 \%$ had retinopathy, and another $1 \%$ had stroke. TAS was found to be significantly lower in patients with Type 2 diabetes (with and without complications) compared to controls $(\mathrm{p}<0.001)$. Similarly, patients with complications of Type 2 diabetes mellitus had significantly lower TAS when compared to patients with diabetes $(\mathrm{p}=0.007)$ (Table 2$)$.

Comet assay image of lymphocytes at magnification $\times 20$ is shown in Fig. 1. Visual scoring of DNA damage is shown in Fig. 2. The cells were classified into three groups based on the level of DNA damage as undamaged (normal) cells, mildly damaged, and highly damaged (comet) cells. The number of highly damaged cells was found to be high in patients with diabetes with complications $(12.4 \pm 9.1 \%)$ and without complications $(8.5 \pm 5.9 \%)$ compared to controls $(2.1 \pm 1.3 \%)$. Significant differences were observed in the level of DNA damage in patients with diabetes with and without complications compared to controls $(\mathrm{p}<0.001)$. Similarly, there were significant differences in the level of DNA damage in patients with diabetes with and without complications $(\mathrm{p}=0.005)$. Increase of DNA damage and diminished TAS in patients with complications reveals that oxidative stress was higher in patients with diabetes compared to controls.

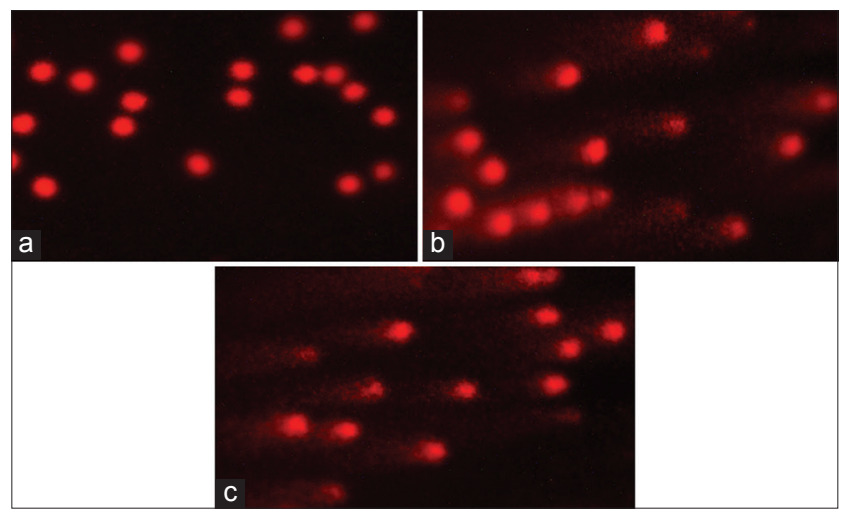

Fig. 1: Analysis of single-cell gel electrophoresis (Comet assay) showing normal and damaged cells at $\times \mathbf{2 0}$ magnification using fluorescent microscope (a) Control group (b) Type 2 diabetic group (c) Type 2 diabetic group with complications

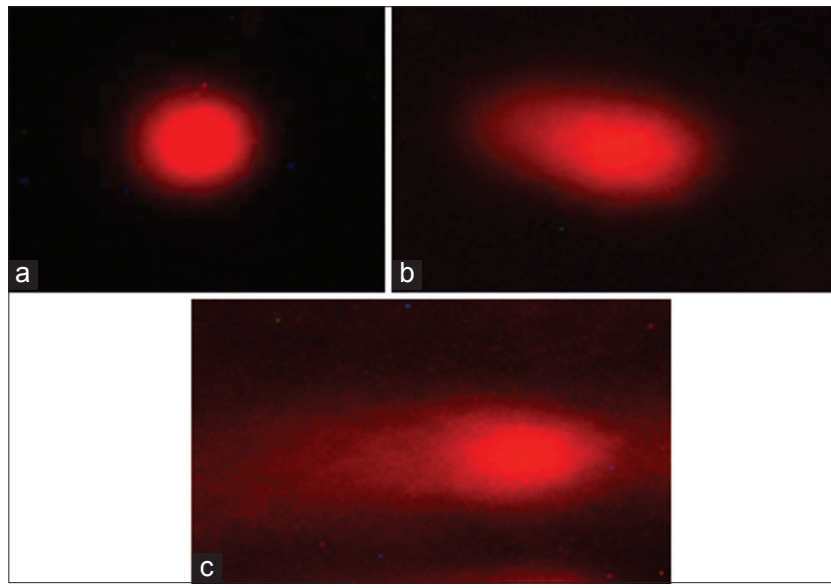

Fig. 2: Visual scoring of DNA damage (a) Undamaged (b) mildly damaged (c) highly damaged 
Table 1: Clinical characteristics of the controls and the Type 2 diabetic patients

\begin{tabular}{llll}
\hline Characteristics & Controls $(\mathbf{n = 1 0 0})$ & Patients with Type 2 diabetes & \\
\cline { 3 - 4 } & & Without complications (n=100) & With complications (n=100) \\
\hline Sex (Male/Female) & $54 / 46$ & $50 / 50$ & $60 / 40$ \\
Age (years), mean \pm SD & $40.9 \pm 10.0$ & $48.2 \pm 9.4$ & $55.2 \pm 7.2$ \\
Duration (years), mean \pm SD & NA & $6.5 \pm 5.7$ & $10.6 \pm 6.7$ \\
Fasting glucose (mmol/L) & $6.07 \pm 0.49$ & $12.6 \pm 3.7$ & $12.7 \pm 3.9$ \\
HbA $_{1 \text { c } \% \text { ), mean } \pm S D}$ & $5.44 \pm 0.5$ & $8.7 \pm 1.6$ & $8.9 \pm 1.8$ \\
Family history (\%) & NA & 35 & 45 \\
Hypertension (\%) & NA & 23 & 26 \\
Dyslipidemia (\%) & NA & 29 & 30 \\
\hline
\end{tabular}

Data presented as mean \pm SD. NA: Not applicable, $\mathrm{HbA}_{1 c}$ : Hemoglobin $\mathrm{A}_{1 \mathrm{c}}$, SD: Standard deviation

Table 2: TAS and various level of DNA damage in the study population

\begin{tabular}{llll}
\hline Parameters & Controls $(\mathbf{n = 1 0 0})$ & Patients with Type 2 diabetes & \\
\cline { 3 - 4 } & & Without complications $(\mathbf{n = 1 0 0})$ & With complications $(\mathbf{n = 1 0 0})$ \\
\hline TAS $(\mu$ mol/L), mean \pm SE & $967.6 \pm 22.1^{* *}$ & $627.4 \pm 20.7^{* *}$ & $579.4 \pm 17.5^{* *}$ \\
Intact cells $(\%)$, mean \pm SD & $90.2 \pm 3.2$ & $67.0 \pm 13.6$ & $60 \pm 16.0$ \\
Mildly damaged $(\%)$, mean \pm SD & $7.6 \pm 2.7$ & $24.0 \pm 8.9$ & $27.7 \pm 9.5$ \\
Highly damaged (\%), mean \pm SD & $2.1 \pm 1.3^{* *}$ & $8.5 \pm 5.9^{* *}$ & $12.4 \pm 9.1^{* *}$ \\
\hline
\end{tabular}

TAS: Total antioxidant status, ${ }^{* *} \mathrm{p}<0.01$ : Statistically significant. SD: Standard deviation, SE: Standard error

Correlation analysis showed that there is no association between age, duration, sugar level, $\mathrm{HbA}_{1}$, TAS, and DNA damage in patients with Type 2 diabetes mellitus (Table 3). Even though there was a decrease in TAS and increase in DNA damage in patients with diabetes with complications, there was no correlation found between DNA damage and TAS in both patients with and without complications.

\section{DISCUSSION}

Free radicals are known to play a definite role in a wide variety of pathological manifestations of pain, inflammation, cancer, diabetes, Alzheimer's disease, hepatic damage, etc. Antioxidants fight free radicals and protect us from various diseases [22]. Type 2 diabetes is a heterogeneous disease with both genetic and environmental contributory factors, involved multiple defects in insulin action and insulin secretion leads to hyperglycemia and affecting nearly $10 \%$ of the population worldwide [23]. In the present study, DNA strand breaks and TAS were examined as a measure of oxidative stress biomarkers in patients with Type 2 diabetes (with and without complications) and controls.

\section{Association between TAS and Type 2 diabetes mellitus}

The present study shows a reduction in TAS in patients with diabetes compared to controls. Studies conducted among different populations including Ghanaian, Nigerian, Chinese, Italian, and Indian have also reported a decrease in TAS in Type 2 diabetes mellitus patients when compared to controls [24-28]. However, there also certain contradictory results suggesting an increase in TAS in patients with diabetes [29]. This discrepancy may be due to variation in lifestyle habits and genetic background of the studied population.

TAS was also found to be decreased in patients with complications such as coronary artery disease, peripheral vascular disease, stroke, neuropathy, nephropathy, retinopathy, and foot ulcer. A study conducted in Egyptian population reported that depletion of the TAS is associated with diabetic complications [30]. Furthermore, another study has reported a significant decrease in TAS in patients with diabetic neuropathy [31]. A study conducted in Brazilian population suggested that assessment of TAS could provide additional information about the risk of foot ulcer in patients with diabetes mellitus [32]. This suggests that the patients with diabetes should be treated with antioxidants so that the further onset of complications could be prevented.
Table 3: Correlation analysis of age, duration of diabetes, sugar level, $\mathrm{HbA}_{1 \mathrm{C}}$, TAS with DNA damage in the study population

\begin{tabular}{|c|c|c|c|c|}
\hline \multirow[t]{3}{*}{ Variables } & \multicolumn{4}{|c|}{ Patients with Type 2 diabetes } \\
\hline & \multicolumn{2}{|c|}{$\begin{array}{l}\text { Without } \\
\text { complications }(n=100)\end{array}$} & \multicolumn{2}{|c|}{$\begin{array}{l}\text { With } \\
\text { complications }(n=100)\end{array}$} \\
\hline & $\mathbf{r}$ & p & $\mathbf{r}$ & p \\
\hline Age & 0.04 & 0.6 & -0.13 & 0.17 \\
\hline Duration & -0.07 & 0.43 & 0.27 & 0.005 \\
\hline Sugar level & -0.03 & 0.7 & 0.07 & 0.4 \\
\hline $\mathrm{HbA}$ & -0.06 & 0.51 & -0.01 & 0.91 \\
\hline TAS & -0.19 & 0.05 & -0.07 & 0.46 \\
\hline
\end{tabular}

TAS: Total antioxidant status, $\mathrm{HbA}_{1 \mathrm{c}}$ : Hemoglobin $\mathrm{A}_{1 \mathrm{C}}$

Association between DNA damage and Type $\mathbf{2}$ diabetes mellitus In the present study, the extent of DNA damage was found to be higher in patients with diabetes compared to controls. Similarly, another study conducted in Egyptian population indicated that patients with diabetes have more oxidative DNA damage than controls [33]. It has been suggested that poor glycemic control might further aggravate the damage. Several studies have shown that elevated glucose level may result in oxidative stress. This has been reported both experimental diabetes in animals and in patients with diabetes [34-36].

The results of the present study showed that extent of DNA damage was higher in patients with diabetes with complications compared to controls. Significantly higher DNA damage was observed in patients with diabetic nephropathy compared to controls among Chinese and Indian population [7,37]. It has been reported that oxidative stress plays a substantial role in the development and progression of diabetic neuropathy [38]. Another study indicated that high glucose levels in vitro may impair cellular DNA repair and increase DNA cleavage [39].

Association between TAS, DNA damage, and Type 2 diabetes mellitus

In the present study, no correlation between age, duration of diabetes, sugar level, $\mathrm{HbA}_{1 c}$, TAS, and DNA damage was observed. A previous study conducted in Type 2 diabetes mellitus $(n=60)$ and controls $(n=60)$ indicated that oxidative stress ratio and DNA damage was found to be increased in patients than in controls [40]. A study conducted among Bangladeshi population has also reported that DNA damage is closely 
associated with a significant reduction in the patient's antioxidant contents and with upregulation of pro-oxidant-induced DNA damage, suggesting decreased efficacy of DNA repair in patients with Type 2 diabetes [41]. When the extent of DNA damage was associated with fasting glucose and $\mathrm{HbA}_{1 \mathrm{C}}$ in Iranian population with Type 2 diabetes mellitus, a positive correlation was observed between them [42]. A study conducted in Mexican population indicated a lack of association between diabetes and DNA damage [43]. Another study conducted in Egyptian population also did not find any correlation between duration of diabetes and DNA damage. The discrepancy between different studies is due to the difference in glycemic control, duration of diabetes, or the type of cells used in the comet assay [44].

In our study, we found increased level of fasting glucose and $\mathrm{HbA}_{1 \mathrm{c}}$ level in patients with diabetes than controls which may be because of poor control of blood sugar level in patients with diabetes. Parameters including age, duration, poor glycemic control, family history, hypertension, and dyslipidemia may aggravate the disease and its complications. The results of the present study showed that there was increased oxidative DNA damage and decreased TAS in patients with diabetes (with and without complications) compared to control groups. The study confirms that hyperglycemia contributes to increased oxidative stress and decreased TAS, which would lead to further increase in DNA damage in patients with diabetes with complications. Therefore, it is suggested that the assessment of DNA damage might serve as a diagnostic tool for preventing further development of complications of diabetes mellitus.

\section{CONCLUSION}

We suggest further DNA damage and onset of complications in Type 2 diabetes mellitus could be prevented by counteracting the oxidative stress and reversing the DNA damage by therapeutic interventions using appropriate antioxidants.

\section{ACKNOWLEDGMENT}

Financial assistance by University Grants Commission-Major Research Project, New Delhi, to Principal Investigator Dr. W. Isabel is greatly acknowledged.

\section{REFERENCES}

1. Inzucchi S, Bergenstal R, Fonseca V, Gregg ED, Mayer-Davis B, Spollett G, et al. American Diabetes Association. Diagnosis and classification of diabetes mellitus. Diabetes Care 2010;33(1):S62-9.

2. Brownlee M. Biochemistry and molecular cell biology of diabetic complications. Nature 2001;414(6865):813-20.

3. Brownlee M, Cerami A, Vlassara H. Advanced glycosylation end products in tissue and the biochemical basis of diabetic complications. N Engl J Med 1988;318(20):1315-21.

4. Greene DA, Lattimer SA, Sima AA. Sorbitol, phosphoinositides, and sodium-potassium-ATPase in the pathogenesis of diabetic complications. N Engl J Med 1987;316(10):599-606.

5. Koya D, King GL. Protein kinase C activation and the development of diabetic complications. Diabetes 1998;47(6):859-66.

6. Baynes JW. Role of oxidative stress in development of complications in diabetes. Diabetes 1991;40(4):405-12.

7. Pan HZ, Chang D, Feng LG, Xu FJ, Kuang HY, Lu MJ. Oxidative damage to DNA and its relationship with diabetic complications. Biomed Environ Sci 2007;20(2):160-3.

8. Kangralkar VA, Patil SD, Bandivadekar RM. Oxidative stress and diabetes: A review. IJPA 2010;1(1):38-45.

9. Pham-Huy LA, He H, Pham-Huy C. Free radicals, antioxidants in disease and health. Int J Biomed Sci 2008;4(2):89-96.

10. Phillips M, Cataneo RN, Cheema T, Greenberg J. Increased breath biomarkers of oxidative stress in diabetes mellitus. Clin Chim Acta 2004:344(1-2):189-94.

11. Asfandiyarova N, Kolcheva N, Ryazantsev I, Ryazantsev V. Risk factors for stroke in Type 2 diabetes mellitus. Diab Vasc Dis Res 2006;3(1):57-60

12. Bolajoko EB, Mossanda KS, Adeniyi F, Akinosun O, Fasanmade A, Moropane M. Antioxidant and oxidative stress status in Type 2 diabetes and diabetic foot ulcer. S Afr Med J 2008;98(8):614-7.
13. Kashiwagi A. Complications of diabetes mellitus and oxidative stress. Japan Med Assoc J 2001;44(12):521-8.

14. Matough FA, Budin SB, Hamid ZA, Alwahaibi N, Mohamed J. The role of oxidative stress and antioxidants in diabetic complications. Sultan Qaboos Univ Med J 2012;12(1):5-18.

15. Maxwell SR, Thomason H, Sandler D, Leguen C, Baxter MA, Thorpe GH, et al. Antioxidant status in patients with uncomplicated insulin-dependent and non-insulin-dependent diabetes mellitus. Eur J Clin Invest 1997;27(6):484-90.

16. Pinzani P, Petruzzi E, Orlando C, Gallai R, Serio M, Pazzagli M. Serum antioxidant capacity in healthy and diabetic subjects as determined by enhanced chemiluminescence. J Biolumin Chemilumin 1998;13(5):321-5

17. Nisha K, Deshwal RK. Antioxidants and their protective action against DNA damage. Int J Pharm Pharm Sci 2011;27(28):29.

18. Nandhakumar S, Parasuraman S, Shanmugam MM, Rao KR, Chand P, Bhat BV. Evaluation of DNA damage using single-cell gel electrophoresis (Comet Assay). J Pharmacol Pharmacother 2011;2(2):107-11

19. Benzie IF, Strain JJ. The ferric reducing ability of plasma (FRAP) as a measure of antioxidant power: The FRAP assay. Anal Biochem 1996;239(1):70-6.

20. Tice RR, Agurell E, Anderson D, Burlinson B, Hartmann A, Kobayashi H, et al. Single cell gel/comet assay: Guidelines for in vitro and in vivo genetic toxicology testing. Environ Mol Mutagen 2000;35(3):206-21.

21. Singh NP, McCoy MT, Tice RR, Schneider EL. A simple technique for quantitation of low levels of DNA damage in individual cells. Exp Cell Res 1988;175(1):184-91.

22. Naskar S, Mazumder UK, Pramanik G, Bala A, Haldar PK, Islam A, et al. Comparative in vitro antioxidant activity of different parts of Cocos nucifera (Linn.) on reactive oxygen and nitrogen species. Int $\mathrm{J}$ Pharm Pharm Sci 2011;3(3):104-7.

23. Sarasa DH, Sridhar SE, Prabakaran EG. Effect of an antidiabetic extract of Trigonella foenum-graecum on normal and alloxan induced diabetic mice. Int J Pharm Pharm Sci 2012;4:63-5.

24. Dosoo DK, Rana SV, Offe-Amoyaw K, Tete-Donkor D, Maddy SQ. Total antioxidant status in non-insulin-dependent diabetes mellitus patients in Ghana. West Afr J Med 2001;20(3):184-6.

25. Akinosun OM, Bolajoko EB. Total antioxidant status in Type 2 diabetic patients: Experience at University College Hospital (UCH) Ibadan, Nigeria. Niger J Clin Pract 2007;10(2):126-9.

26. Song F, Jia W, Yao Y, Hu Y, Lei L, Lin J, et al. Oxidative stress, antioxidant status and DNA damage in patients with impaired glucose regulation and newly diagnosed Type 2 diabetes. Clin Sci (Lond) 2007;112(2):599-606.

27. Lodovici M, Giovannelli L, Pitozzi V, Bigagli E, Bardini G, Rotella CM. Oxidative DNA damage and plasma antioxidant capacity in Type 2 diabetic patients with good and poor glycaemic control. Mutat Res 2008;638(1-2):98-102.

28. Rani AJ, Mythili SV. Study on total antioxidant status in relation to oxidative stress in Type 2 diabetes mellitus. J Clin Diagn Res 2014;8(3):108-10

29. Srivatsan R, Das S, Gadde R, Manoj-Kumar K, Taduri S, Rao N, et al. Antioxidants and lipid peroxidation status in diabetic patients with and without complications. Arch Iran Med 2009;12(2):121-7.

30. Opara EC, Abdel-Rahman E, Soliman S, Kamel WA, Souka S, Lowe JE, et al. Depletion of total antioxidant capacity in Type 2 diabetes. Metabolism 1999;48(11):1414-7.

31. Dordevic G, Duric S, Apostolskit S, Dordevic V, Zivkovic M. Total antioxidant blood capacity in patients with Type 2 diabetes mellitus and distal symmetrical polyneuropathy. Vojnosanit Pregl 2008;65(9):663-9.

32. Oliveira AC, Teixeira CJ, Stefanello TF, Carrara MA, Bazotte RB, Sa-Nakanishi AB, et al. Oxidative stress parameters as biomarkers of risk factor for diabetic foot among the patients with Type 2 diabetes. Braz Arch Biol Technol 2014;57(2):223-7.

33. El-Wassef M, El-Saeed GS, El-Tokhy SE, Raslan HM, Tawfeek S, Siam I, et al. Oxidative DNA damage in patients with Type 2 diabetes mellitus. Diabetol Croat 2012;41(4):121-7.

34. West IC. Radicals and oxidative stress in diabetes. Diabet Med 2000;17(3):171-80.

35. Rawi SM, Mourad IM, Sayed DA. Biochemical and changes in experimental diabetes before and after treatment with Mangifera indica and Psidium guava extracts. Int J Pharm Bio Sci 2011;2(2):29-41.

36. Piwkowska A, Rogacka D, Audzeyenka I, Jankowski M, Angielski S. High glucose concentration affects the oxidant-antioxidant balance in cultured mouse podocytes. J Cell Biochem 2011;112(6):1661-72. 
37. Reddy SG, Kumar RG, Spurthi MK, Saraswati M, Rani SH. Oxidative stress and DNA damage in diabetic nephropathy. J Anal Bio Sci 2013;36(2):175-80.

38. Kasznicki J, Kosmalski M, Sliwinska A, Mrowicka M, Stanczyk M, Majsterek I, et al. Evaluation of oxidative stress markers in pathogenesis of diabetic neuropathy. Mol Biol Rep 2012;39(9):8669-78.

39. Kaneto H, Fujii J, Suzuki K, Kasai H, Kawamori R, Kamada T, et al. DNA cleavage induced by glycation of $\mathrm{Cu}, \mathrm{Zn}$-superoxide dismutase. Biochem J 1994:304:219-25.

40. Angeline T, Caroline JC, Rani JJ, Asirvatham AJ, Isabel W. Analysis of DNA damage, plasma lipid peroxidation, and antioxidant status in Type 2 diabetes mellitus patients among a South Indian population. Int J Diab Dev Ctries 2015;35(3):491-5.
41. Arif M, Islam MR, Waise TM, Hassan F, Mondal SI, Kabir Y. DNA damage and plasma antioxidant indices in Bangladeshi Type 2 diabetic patients. Diabetes Metab 2010;36(1):51-7.

42. Goodarzi MT, Navidi AA, Rezaei M, Babahmadi-Rezaei H. Oxidative damage to DNA and lipids: Correlation with protein glycation in patients with Type 1 diabetes. J Clin Lab Anal 2010;24(2):72-6.

43. Ibarra-Costilla E, Cerda-Flores RM, Dávila-Rodríguez MI, Samayo-Reyes A, Calzado-Flores C, Cortés-Gutiérrez EI. DNA damage evaluated by comet assay in Mexican patients with Type 2 diabetes mellitus. Acta Diabetol 2010;47 Suppl 1:111-6.

44. Blasiak J, Arabski M, Krupa R, Wozniak K, Zadrozny M, Kasznicki J, et al. DNA damage and repair in Type 2 diabetes mellitus. Mutat Res 2004;554(1-2):297-304. 